\title{
19. MICROSTRUCTURAL CONTROLS ON STRAIN LOCALIZATION IN OCEAN CRUST DIABASES: EVIDENCE FROM HOLE 504B
}

\author{
Susan M. Agar ${ }^{2}$ and Frederic C. Marton ${ }^{2}$
}

\begin{abstract}
Microstructural investigations of ocean crust samples provide a complementary approach to both marine surveys and laboratory experiments. The recovery of relatively undeformed diabases from Deep Sea Drilling Project (DSDP)/Ocean Drilling Program (ODP) Hole 504B provides a first opportunity to examine a reference section of microstructural features that influence strain localization at depths of $2 \mathrm{~km}$ in the ocean crust. Syn- and post-crystallization features in plagioclase and augite crystals have been examined by optical microscopy and secondary and backscattered electron imaging. These features show a strong influence of modal composition and primary textures on early sites of strain localization. Thermal cracking and subsequent alteration intensities and distribution are strongly phase dependent. A consistently higher intragranular fracture density is observed in augite crystals relative to plagioclase. The impact of alteration on the mechanical response of diabases is likely to depend on the primary textural characteristics. Even where extensive augite alteration occurs, the rock remains supported by a framework of weakly altered plagioclase crystals. The Hole 504B diabases from Leg 140 provide a valuable comparison for future studies of more deformed sections likely to be encountered at depth. Advances in constraining the detailed rheology of the ocean crust at spreading centers would benefit from experimental deformation of texturally diverse diabase and gabbro samples.
\end{abstract}

\section{INTRODUCTION}

Constraining the detailed rheological evolution of the ocean crust at spreading centers is a key aspect for developing models of constructive margin initiation, propagation, and modification. The nature and distribution of failure mechanisms at actively accreting boundaries are also critical for understanding ocean crust seismicity. As newly formed ocean crust moves off-axis, variable magmatic, thermal, alteration, and deformation histories influence spatial and temporal strength variations. Increasingly detailed seafloor observations have highlighted the shallow crustal deformation and strain partitioning directly influencing the evolution of fine-scale topography and fluid circulation around a spreading center (Macdonald, 1982; Hey et al., 1986; Kappel and Normark, 1987; Johnson and Embley, 1990; Macdonald et al., 1991). The distribution and nature of failure in ocean crust lithologies has not only been affected by varying environmental parameters but also by the evolution of physical and chemical lithological characteristics during the ridge-crest-ridge-flank transition. The impact of lithological and environmental variables on the rheological properties of the ocean crust has yet to be fully assessed either by experiment or direct observation of an in-situ ocean crust reference section. Marine surveys have yielded valuable insights to constructive margin evolution, but the controls on strain localization, strain rate variations, stress states, and the nature of deformation mechanisms remain elusive because of the low resolution of most seafloor investigations. Experimental data have tended to emphasize monomineralic assemblages representative of bulk mantle properties or employed pristine, unaltered polyphase assemblages (Griggs et al., 1960; Goetze and Brace, 1972; Shelton and Kronenberg, 1978; Caristan, 1982; Rutter et al., 1985). Direct sampling of the ocean crust, however, has demonstrated clearly the broad spectrum of textures and assemblages which result from variable cooling and alteration histories (e.g., Helmstaedt and Allen, 1977; Fox and Stroup, 1981; Vanko and Batiza, 1992; Cannat et al., 1992; Kowallis

\footnotetext{
${ }^{1}$ Erzinger, J., Becker, K., Dick, H.J.B., and Stokking, L.B. (Eds.), 1995. Proc. ODP, Sci. Results, 137/140: College Station. TX (Ocean Drilling Program). U.S.A
}

et al., 1982) in the upper ocean crust. The roles of different failure mechanisms which operate under upper ocean crust conditions in heterogeneous lithologies have not been investigated in detail. The development of more realistic ocean crust rheology models is therefore hindered by a lack of appropriate experimental deformation data for representative lithologies and detailed microstructural investigations of ocean crust samples.

Microstructural investigations of ocean crust samples can provide a complementary approach to both marine surveys and laboratory experiments by establishing (1) the range of textures and petrological characteristics of ocean crust protoliths and (2) the spatial and temporal variations of deformation mechanisms imposed on these protoliths. The recovery of relatively undeformed diabases from the deepest borehole in the ocean crust to date, Deep Sea Drilling Project/Ocean Drilling Program (DSDP/ODP) Hole 504B, provides a first opportunity to examine a reference section of the microstructural features which influence strain localization at depths of $2 \mathrm{~km}$ in the ocean crust.

Experimental studies of crystalline rocks have revealed several strain softening and hardening phenomena which generate instabilities and result in strain localization (Hobbs et al., 1990). Within the predominantly brittle field of deformation, fault generation has been found to be strongly dependent upon microcrack geometries, their interactions and crack network configurations (Griffith, 1920; Sprunt and Brace, 1974; Kranz, 1983; Hadizadeh and Rutter, 1983; Wong, 1982). The evolution of the microcrack population, in turn, is strongly dependent upon mineralogy, grain size, orientation of the principal stresses and the confining pressure (Wawersik and Brace, 1971; Simmons and Richter, 1976). Consequently, textural variations may cause variations in fracture strength between petrologically similar rocks and deviations from experimentally fracture strength (Hoagland et al., 1973; Paterson, 1978). The evolution of crack arrays during cooling of ocean crust lithologies is therefore an important factor affecting spreading center rheology as the microcrack populations will influence the timing and location of failure, and generate stress inhomogeneities and elastic anisotropies. They also play a critical role in the alteration history of the ocean crust which in turn will modify microcrack characteristics. In this paper we examine the primary mineralogy and textural variations, and the nature and distribution of alteration phases and fractures. We then discuss their significance and potential role in post-crystallization strain localization. 


\section{HOLE 504B}

DSDP/ODP Hole 504B is located $200 \mathrm{~km}$ south of the Costa Rica Rift at $1^{\circ} 13.611^{\prime} \mathrm{N}, 83^{\circ} 43.818^{\prime} \mathrm{W}$. The 5.9-Ma crust drilled at Hole 504B lies midway between the Ecuador and Panama fracture zones. Hole 504B therefore accesses ocean crust removed from the complications of cooling or deformation related to transform zones. The site also provides complementary data for deformation histories in ophiolite complexes which may be modified by obduction related deformation and alteration. The borehole reaches $2000.4 \mathrm{mbsf}$ (meters below seafloor) and penetrates $1725.9 \mathrm{~m}$ of basement. In Leg 140 a section of $378.9 \mathrm{~m}$ was cored with an average recovery of $12.6 \%$. Previous investigations of the deformation in the ocean crust revealed by Hole 504B include measurements of macroscopic fractures on core sections (Adamson, 1985; Agar, 1990), borehole televiewer studies of borehole breakouts, and Formation MicroScanner (Anderson and Zoback, 1983; Morin et al., 1990; Newmark et al., 1984, 1985) and microstructural analysis of deformation zones located within the pillow-dike transition (Agar, 1991). Although the crust in Hole 504B is not strongly deformed, a wide range of cataclastic deformation is preserved in the core. The range of brittle failure zones includes a stockwork zone of alteration (Honnorez et al., 1985), which has been inferred to be a shallow fault zone on the basis of geochemical (Becker, Sakai, et al., 1988), magnetic (Kinoshita et al., 1989), and structural data (Agar, 1991). The distinction of primary cataclastic features, such as pillow breccias and brecciated intrusive margins from syn- or post-magmatic faulting is not always clear in the Hole 504B core. Structural relations indicate that faulting and intrusive breccias were sometimes generated synchronously, with deformation localized along the mechanical contrast boundary at dike margins. Fault-dominated deformation has been interpreted where a preferred orientation of fractures, combined with local increases in fracture intensity over meter-wide zones and localized cataclasis occur (Agar, 1991). Dilation during slip on these shallow faults may have transiently diverted fluid flow, generating the localized "stockwork-like" mineralization at 910-930 mbsf (Agar, 1991).

The deeper penetration achieved during Leg 140 accessed diabases with generally fine to medium grain sizes and encountered significantly fewer chilled margins than previous drilling legs at Hole 504B. In conjunction with abundant actinolite alteration, these characteristics are thought to indicate the proximity to the dike-gabbro transition zone (Shipboard Scientific Party, 1992). Although the core recovery was very low on Leg 140 , the samples represent a previously unexplored location in in-situ ocean crust. The core contains not only a unique set of microstructural data for comparison with laboratory data but also provides a valuable comparison for shallower core sections where many units have aphanitic or fine-grained phyric textures. Fault rocks were not recovered during Leg 140 but the inferred proximity of the recovered core to the rheologically significant dikegabbro transition provides an important reference. As brittle deformation can obliterate primary textural features even after low strains, a comparison for lithologically similar but deformed sections is essential for subsequent core recovery.

\section{DIABASE TEXTURAL CHARACTERISTICS}

Twenty-eight samples of diabase were acquired for this study from core recovered between depths of $1586 \mathrm{mbsf}$ and $1922 \mathrm{mbsf}$ during Leg 140 (Fig. 1). Shipboard logging of Hole 504B during Leg 140 recorded $11.4 \%$ aphyric, $18.6 \%$ sparsely phyric, and $70.0 \%$ moderately phyric plagioclase-pyroxene-(augite and chrome-bearing augite) olivine diabases. Accessory phases include chrome spinel, Fe-Ti oxides, and magnetite. Grain size is predominantly fine to medium grained but there is an overall increase in grain size relative to previously recovered core sections (Shipboard Scientific Party, 1992). The coarsest unit has an average grain size of $1.5 \mathrm{~mm}$ but the textures remain typical of diabase and not microgabbro. Primary crystallization textures in the selected samples exhibit a range of seriate porphyritic, subophitic, and ophitic textures. Plagioclase typically occurs as euhedral laths in the groundmass, many of which are subophitically enclosed by the outer rims of pyroxene phenocrysts which continued to crystallize during groundmass crystallization (Shipboard Scientific Party, 1992). Augite occurs as prismatic, euhedral to subhedral phenocrysts and anhedral to subhedral crystals in the groundmass. As observed throughout the core (Shipboard Scientific Party, 1992) the selected samples exhibit an average hydrothermal alteration intensity of about $10 \%-20 \%$. This alteration intensity increases locally where clusters of olivine crystal occur or where discrete veins have formed. Clinopyroxene is most commonly altered to actinolite, and plagioclase is altered to albite and chlorite. Fresh olivine occurs rarely and is more frequently represented by olivine pseudomorphs containing talc and magnetite subsequently overprinted by chlorite and mixed-layer clays. Discrete isolated veins $0.5-2.0 \mathrm{~mm}$ wide dissect the core. Chlorite, chlorite plus actinolite, and actinolite are the dominant vein-fill phases, but epidote and quartz are present in later generations of veins (Shipboard Scientific Party, 1992). The majority of fractures in the samples used for this study are intragranular although minor $(<0.5 \mathrm{~mm}$ wide $)$ discrete transgranular veins traverse three of the specimens. No penetrative preferred crystallographic orientation is evident in the samples (N. Pertsev, pers. comm., 1993) and no localized or distributed cataclasis is present. Other core samples show a preferred shape orientation where local flow textures have been identified (Shipboard Scientific Party, 1992).

\section{Syn- and Post-crystallization Microstructures}

Thin sections and polished blocks of specimens were examined optically and under secondary and backscatter electron imaging on JEOL 733 Superprobe using specimen preparation techniques outlined in Agar et al. (1989). Below we outline specific textural and fracture characteristics of selected samples and discuss their significance in terms of strain localization and failure in the upper ocean crust. Examples of textural features studied from previous drilling legs at Hole 504B are also included for comparison.

As observed in other fracture studies of igneous rocks (Richter and Simmons, 1977; Rovetta et al., 1987), syn-crystallization deformation is dominated by dense, intragranular arrays of annealed microcracks that healed by plastic flow during crystallization. These are represented by bands of varying width of melt inclusions that traverse both the pyroxene and plagioclase phenocrysts (Fig. 1). In plagioclase the arrays most frequently align along the $(010)$ cleavage planes but also occur in sub-perpendicular arrays, parallel to (001) cleavages (Fig. 1A, -C). The shapes of the inclusions are commonly elongated along the trace of the healed cracks they occupy. In the augite crystals melt inclusion arrays also follow the traces of cleavage planes (110) and partings along (100). In contrast to the plagioclase arrays the inclusions cluster in broader zones along the healed cracks and exhibit a weaker shape preferred orientation. In thin sections ( $100 \mu \mathrm{m}$ thick), the fluid inclusion arrays can be seen to twist so that they appear to thicken and thin along their length in the section plane (Fig. 1B).

Minor syn-crystallization, intracrystalline deformation is represented by undulose extinction of variable intensity in both plagioclase and augite crystals. Extinction domains overprint hourglass and compositional zoning in augites and intensify at ophitic and subophitic contacts between plagioclase and augite. Some distortion of the crystal lattice is also evident in curved, groundmass plagioclase laths. The olivine crystals are so extensively altered that it is not possible to examine syn-crystallization features (Fig. 1D).

Post-crystallization microcracks are delineated by the presence of hydrothermal minerals which seal them and are also dominated by intragranular cracking (Fig. 2). Plagioclase laths display two subperpendicular fracture arrays, corresponding to cleavage orientations which overprint healed crack arrays. Similarly, in the augites two subperpendicular fracture arrays dominate intracrystalline deformation 

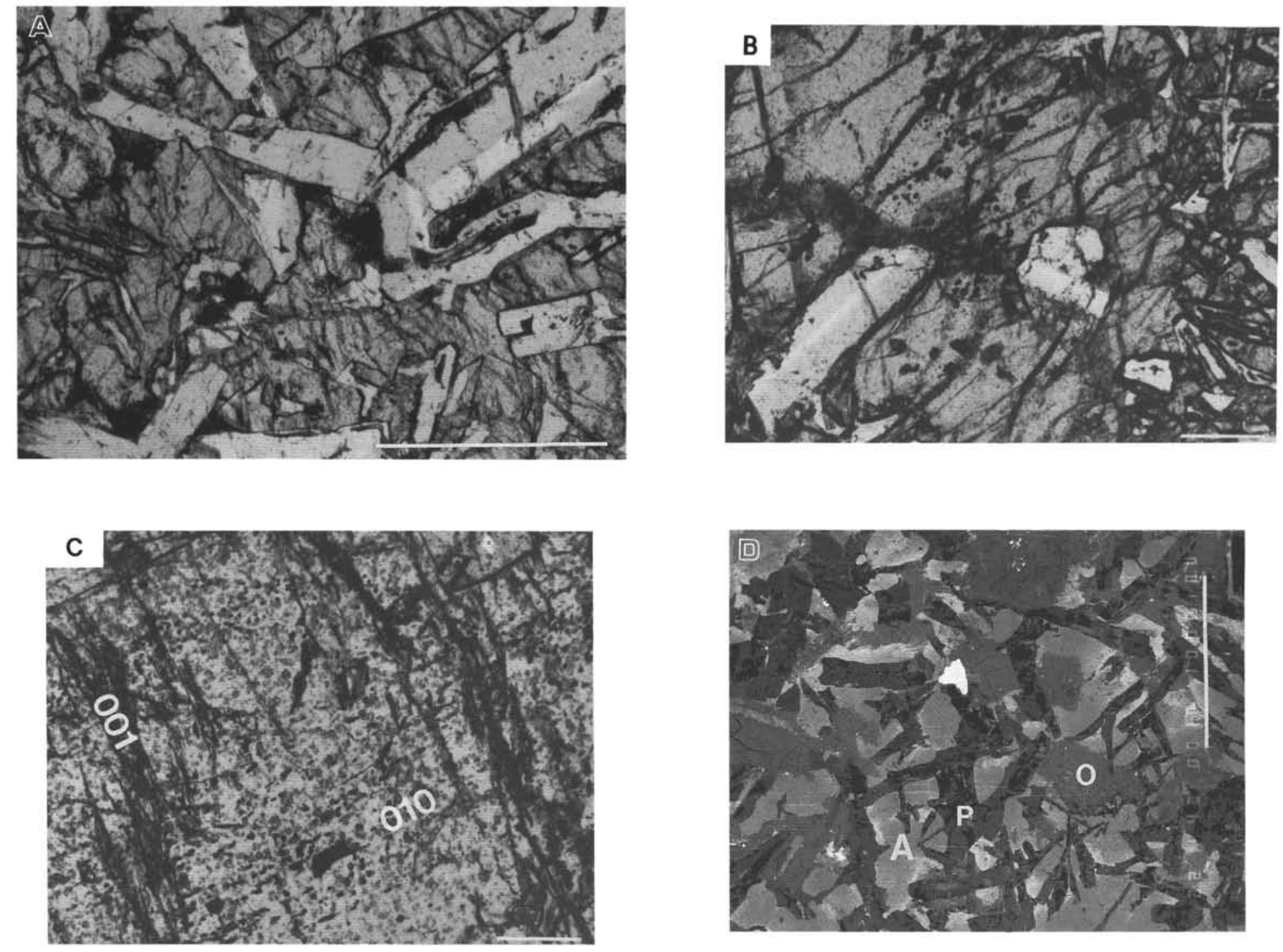

Figure 1. A. Sample 140-504-213R-1, 72-73 cm. Contrasting healed crack arrays in diabases from Leg 140. Augite groundmass crystals display dense, branching arrays of intragranular cracks, whereas plagioclase crystals tend to have more discrete, simple planar intragranular cracks along (001) and (010). Melt inclusions are trapped within healed crack arrays in both phases. Optical photomicrograph. plane polarized light; Scale bar $=0.5 \mathrm{~mm}$. B. Sample 140-504B-210R-1, 30-33 cm. Augite phenocryst containing healed crack arrays that have been reactivated by shrinkage cracks formed during cooling. Trails of melt inclusions are evident within the crystal (dark spots). Thermal cracks have penetrated the ophitic plagioclase inclusion. Optical photomicrograph, cross polarized; scale bar $=0.1 \mathrm{~mm}$. C. Sample 140-504B-200R-3, 10-12 cm. Healed crack arrays in plagioclase crystal containing aligned melt inclusions along (010). The healed cracks are overprinted by thermal cracks filled with alteration phases opening along (001) planes. Scale bar =0.1 mm. D. Sample 140-504B-191R-1, 41-43 cm. Backscatter electron image showing the variation in alteration intensity among plagioclase, augite, and olivine. Olivine crystals $(\mathrm{O})$ are completely altered to talc, serpentine, and magnetite and display shrinkage cracks associated with dehydration during preparation. Augite crystals (A) are partially altered to actinolite and chlorite, predominantly at their grain boundaries. Plagioclase crystals ( $\mathrm{P})$ are altered along thermal cracks by albite (very dark), which has grown into irregular patches and coalesced with surrounding alteration zones. Scale bar $=1000 \mu \mathrm{m}$. 

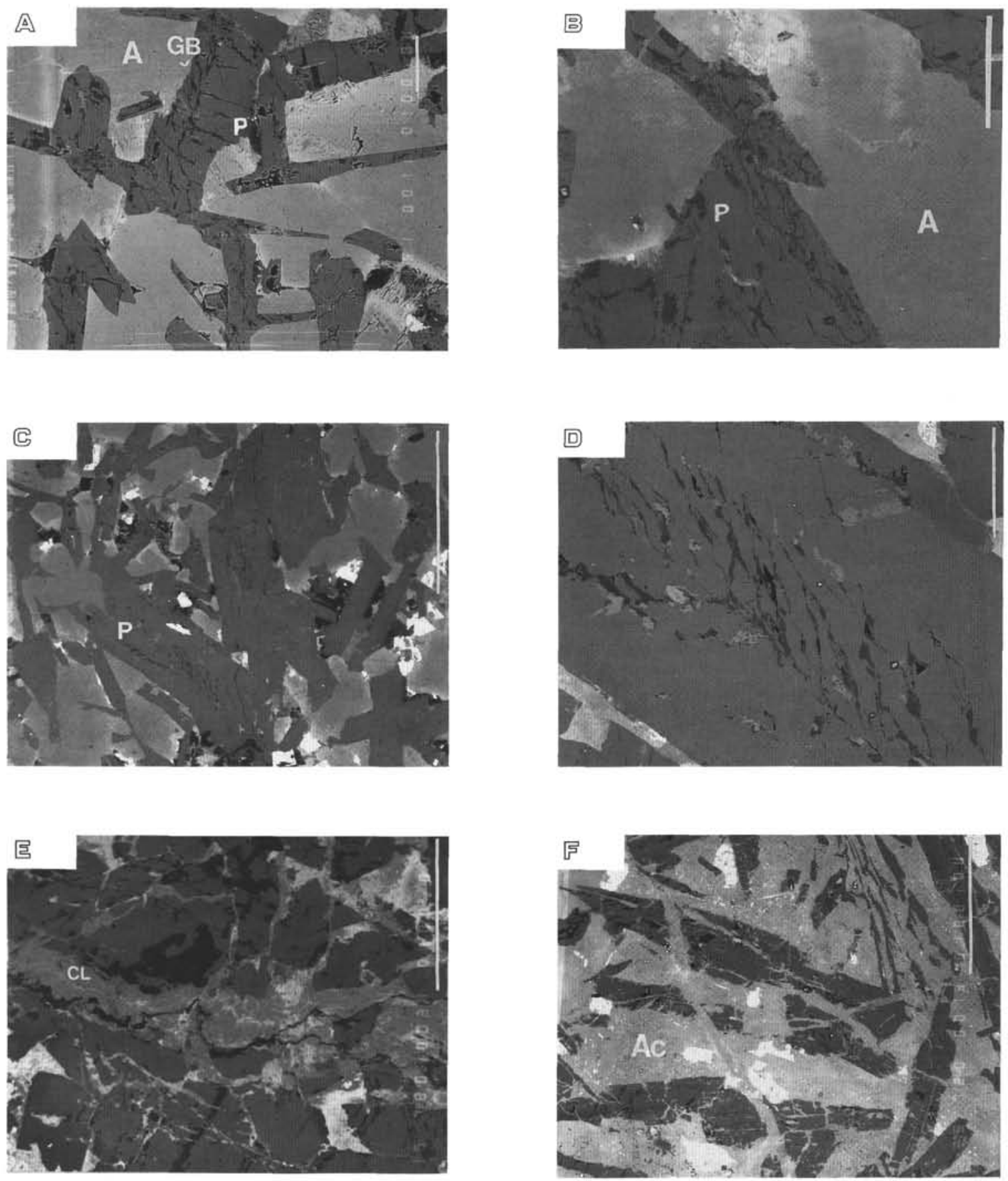

Figure 2. Backscatter scanning electron (BSE) images showing the nature and distribution of microcracks in diabases from Leg I40. A. Sample 140-504B-191R-1, 91-94 cm. Groundmass of plagioclase (dark) and augite (light) crystals. Within the plagioclase crystals (P), albite-filled cracks are controlled predominantly by crystallographic cleavages. Crack geometries have been modified by linkage and coalescence both within grains and adjacent to the grain boundary (GB) with augite (A). Minor chlorite is also present in cracks. Scale bar $=100 \mu \mathrm{m}$. B. Sample 140-504B-191R-1, 91-94 cm. Intergranular cracking between plagioclase phases (P). Cracking has intensified at the boundary with an augite grain (A). Increased branching of cracks filled with albite has resulted in the coalescence of cracks between the two plagioclase grains but has not affected the surrounding augite phases. Scale bar $=100 \mu \mathrm{m}$. C., D. Sample 140-504B-186R-1, 71-76 cm. Diabase groundmass showing internal deformation of the larger plagioclase crystals. (D) shows a close-up of the grain $(\mathrm{P})$ in $(\mathbf{C})$. Intragranular, en-echelon cracks have formed within a narrow zone that parallels (001). Cracks are filled with albite (dark), with minor, subsequent chlorite precipitation. Scale bar for $(C)=100 \mu \mathrm{m}$; scale bar for $(D)=10 \mu \mathrm{m}$. E. Sample 140-504B-209R-2, 20-24 cm. Transgranular actinolite-chlorite vein dissecting a plagioclase crystal. Actinolite fibers do not have a strong preferred orientation although a discrete median line of chlorite $(\mathrm{Cl})$ is evident on the left-hand side of the image. The fragments of the crystal do not appear to have rotated significantly relative to each other. Adjacent to the vein margins, plagioclase crystal fragments are isolated by the pervading alteration phases. Scale bar $=500 \mu \mathrm{m}$. F. Sample 140-504B-190R-1, 91-94 cm. Augite crystals in the groundmass have been pervasively altered to actinolite (Ac), leaving fragments of plagioclase crystals suspended in a matrix of fibrous actinolite. Both the matrix and the crystals are dissected by discrete transgranular veins of actinolite. Remnants of early albite alteration can be seen in the plagioclase. The bright phase is magnetite. Scale bar $=500 \mu \mathrm{m}$. 
with subordinate cracks forming along (100). In augite the cleavage cracks clearly reactivate one or both sets of healed crack arrays with more continuous hairline cracks overprinting the discontinuous, overlapping and branching "bands" of melt inclusions (Fig. 1B). In plagioclase the $(001)$ planes are dominant with individual cracks often crossing the entire crystal. The close relationship of crystallographic cleavage planes to fracture orientations suggests that the majority of intragranular cracks are shrinkage cracks formed during cooling.

Intragranular fracturing is not always evenly distributed throughout phases. Variable intragranular fracture intensities occur both within individual crystals and between crystals of the same phase in one thin section (Fig. 2). Fracture intensity often increases toward one margin of a plagioclase grain in contact with an augite crystal (Fig $2 \mathrm{~A})$. The augite crystals in this case rarely show a similar increase in fracture density towards their margins. In some cases such strain localization is transmitted across crystals (Fig. 2B) by linking intragranular cracks. In such examples the intragranular cracks display increased branching and are still restricted to plagioclase crystals. Intragranular cracking in augite frequently intensifies at the margins of the ophitic and subophitic inclusions of plagioclase, sometimes traversing them undeflected. Intragranular cracking also intensifies at the numerous angular point contacts located around plagioclase lath margins (Fig. 1A,-B). A similar effect is seen in the phyric basalts of the upper basement section of Hole 504B from Leg 69 (Fig. 3) but their deformation is accommodated by open cracks that probably formed as a consequence of stress release during recovery. These examples, however, show clearly the distribution and intensity of the stored elastic strain energy within the phenocryst phases arising during crystallization of subophitic textures. In contrast to the plagioclase laths in the diabases from Leg 140, the margins of the augite crystals are less prone to irregular, angular protrusions and have less impact on the intragranular crack arrays in the plagioclase.

Although grain boundaries appear to dominate fracture density patterns, fracture intensity also increases within crystals. Within several plagioclase crystals, en-echelon arrays of cracks are located in the center of the crystal (Fig. 2C, -D). Individual "pull-apart" structures, filled with alteration phases, link along arrays of hairline cracks within 100- to 200- $\mu \mathrm{m}$-wide zones. We suggest that these represent microshear zones, bound by $(010)$ cleavage planes, accommodating deviatoric stresses during cooling.

Backscattered electron (BSE) imaging shows that many of the thermal cracks provide fluid access networks and serve as sites for subsequent precipitation of alteration phases (Fig. 4). The distribution and intensity of alteration varies on the grain scale corresponding with the variations in fracture intensity outlined above. Within plagioclase two or three distinct generations of fracture fills (albite, chlorite, and actinolite) are evident (Fig. 4A, -B). Early albite fills thermal cracks, which are subsequently crosscut and overprinted by chlorite and actinolite precipitation. Not all albite cracks are subsequently exploited by other alteration phases. In some instances actinolite and chlorite alteration are confined to one dominant set of thermal cracks or a restricted percentage (often $30 \%-50 \%$ ) of the preexisting cracks (Fig. 4A). Sealed cracks in plagioclase are generally less than $10 \mu \mathrm{m}$ wide but their margins are disrupted by irregular patches of the albite alteration which have coalesced as they penetrated the surrounding crystal from the thermal cracks where they nucleated. Where dense clusters of altered olivine crystals arise the alteration of plagioclase correspondingly intensifies.

The thermal cracks in augite crystals are also exploited by actinolite alteration but irregular patches of actinolite within augite crystals are also common. An enhanced permeability due to the higher cooling fracture intensity probably facilitated fluid access, resulting in more extensive augite alteration. BSE imaging shows the localization of early alteration along grain boundaries (Fig. 5). In addition to compositional zoning within some of the augites, a weak subgrain structure is evident under high contrast BSE imaging which reveals subtle variations in lattice orientations (Fig. 5). Where augite crystals have been entirely replaced by actinolite, the grain boundaries of the original phenocrysts are still evident. Within individual pseudomorphs the actinolite/chlorite fibers show a domainal preferred orientation (Fig. 4D). Most of the plagioclase grain boundaries are sharp and irregular but ragged margins have developed locally where alteration phases have corroded the groundmass (Fig. 4E, -F).

Transgranular cracks and veins in the diabases are commonly filled with actinolite and chlorite and dissect both plagioclase and augite crystals. Some clearly postdate the actinolite alteration of augite phenocrysts and groundmass (Fig. 2F). In 100- $\mu \mathrm{m}$ wide zones adjacent to the transgranular fractures, thermal cracks have frequently reopened and coalesced to isolate fragments of corroded phenocrysts within a the fracture network (Fig. 2E, -F). Local preferred orientations of fibrous actinolite and chlorite occur within the veins and between crystal fragments (Figs. 2E, 5A, -B) but are rarely consistent over the entire length of the vein. This may indicate that such veins formed as a consequence of replacement of primary phases along a localized flow path as opposed to precipitation of hydrothermal phases in a dilational fracture. In Sample 140-504B-190R-1, 91-94 $\mathrm{cm}$, fibrous actinolite and chlorite grow obliquely to the margins of a $200-\mu \mathrm{m}$-wide vein. Within this vein, minor $(<50 \mu \mathrm{m})$ displacements of dismembered plagioclase phenocrysts are evident, suggesting local deviatoric stresses which may have been induced by slight compaction after the hydrous phase precipitation. There is, however, no evidence for significant shear displacement along veins.

In a transect across the wall of a transgranular actinolite vein, several systematic changes in the physical characteristics of the groundmass phases are evident (Fig. 5). Within the vein, isolated fragments of plagioclase, strongly altered to albite, are suspended in a fibrous matrix of actinolite (Fig. 5A). The fragments are much smaller than the average plagioclase crystal grain size, suggesting that they are relicts of larger grains replaced by alteration. The optical continuity between many of the fragments also suggests that there has been little rotation which might be associated with cataclasis or rapid strain rates associated with fracturing under elevated pore-fluid pressures. Domains of straight and slightly curved fibers of actinolite appear to have grown during the separation of the fragments, although no preferred orientation of the fibers is evident for the whole vein (Fig. 5B). Comparisons with phyric basalts from the upper section of Hole 504B reveal some similarity with textures of isolated fragments within a matrix of alteration materials (Fig. 3). These examples, however, contrast with diabase textures from Leg 140 in that the fragments are generally more angular and frequently have a conchoidal fracture surface. The fragments from the upper sections of Hole 504B comprise both lithic and individual crystal clasts with a wide clast size distribution. They have also rotated relative to each other within the matrix of alteration phases. Intact plagioclase fragments are present $2 \mathrm{~mm}$ away from the margin of the vein in the Hole 504B diabase (Fig. 5C), but display a high $(30 \%-50 \%)$ percentage of albite replacement. Relict grains of clinopyroxene are evident although completely replaced by actinolite. Within $4 \mathrm{~mm}$ primary augite crystals are present but their margins are altered to actinolite and the plagioclase crystals are variably altered (Fig. 5D). At $7 \mathrm{~mm}$ the distribution of alteration in the phases is more even and the distinct primary grain morphologies are evident in the groundmass (Fig. 5E).

\section{FRACTURE DENSITIES}

As a preliminary investigation we have examined fracture densities in thin sections and polished blocks both optically and under the scanning electron microscope (SEM) to assess the contrasting response of augite and plagioclase during cooling and alteration. Fracture densities have been calculated using the linear intercept method (Wang et al., 1989; Fredrich and Wong, 1986) on 100× optical images compiled into photomosaics. Each mosaic covered an area of at least $100 \mathrm{~mm}^{2}$. As the samples display no crystallographic or shapepreferred orientation, two arbitrary orthogonal directions were used 

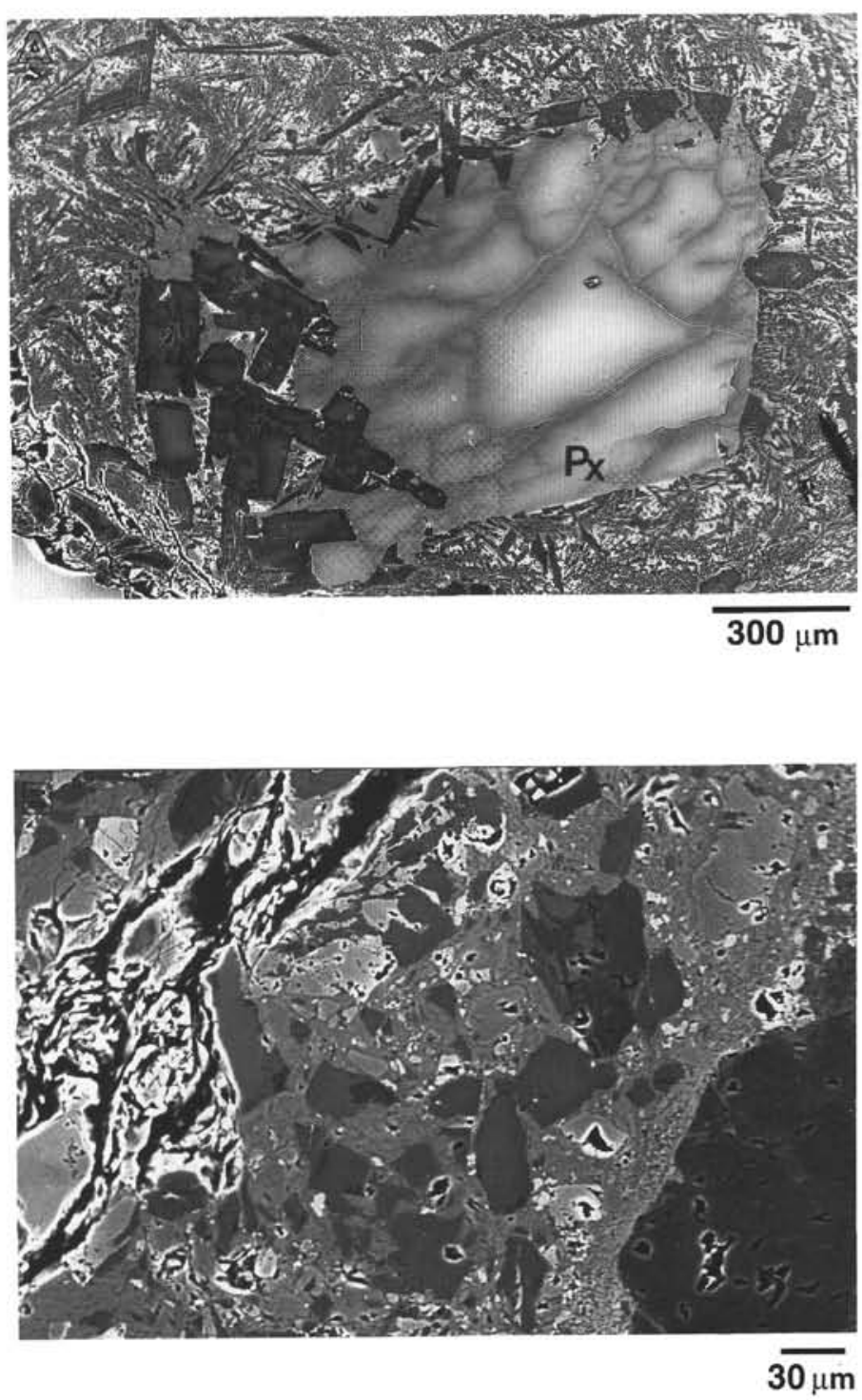

Figure 3. BSE images of phyric basalts and diabases from previous legs at Hole 504B. A. Sample 69-504B-21R-2-1215, $125-128 \mathrm{~cm}$. Phyric basalt from a lava flow unit $424 \mathrm{mbsf}$ at Hole 504B. The pyroxene phenocryst $(\mathrm{Px})$ shows the variation in cracking intensity associated with the grain boundary where subophitic plagioclase (dark) crystals are embedded. See text for discussion. Scale bar $=300 \mu \mathrm{m}$. B. Sample 83-504B-92R-2-5B.

Cataclastic zone in a massive dike unit from Hole 504B. In contrast to isolated plagioclase fragments in the Leg 140 diabases, the fragments within this zone are angular to subangular and have rotated relative to one another. See text for discussion. Scale bar = $30 \mu \mathrm{m}$. C. Sample 69-504B-2IR-2-1218, 145-146. Hyaloclastite breccia in a phyric basalt in a lava flow unit from Hole 504B. In this example both lithic and crystal clasts are suspended in an altered, glassy matrix. See text for discussion. Scale bar $=100 \mu \mathrm{m}$.

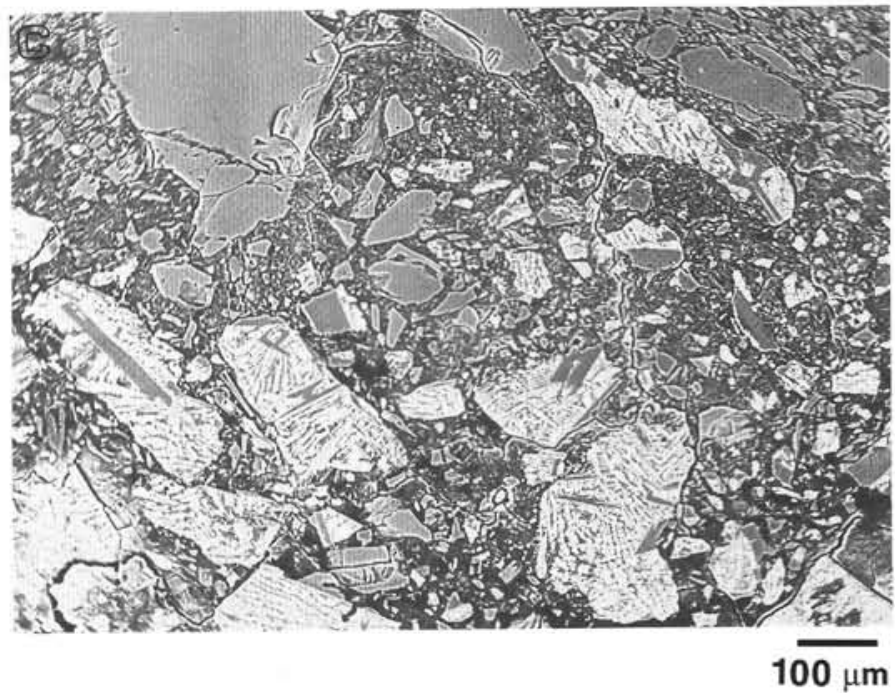



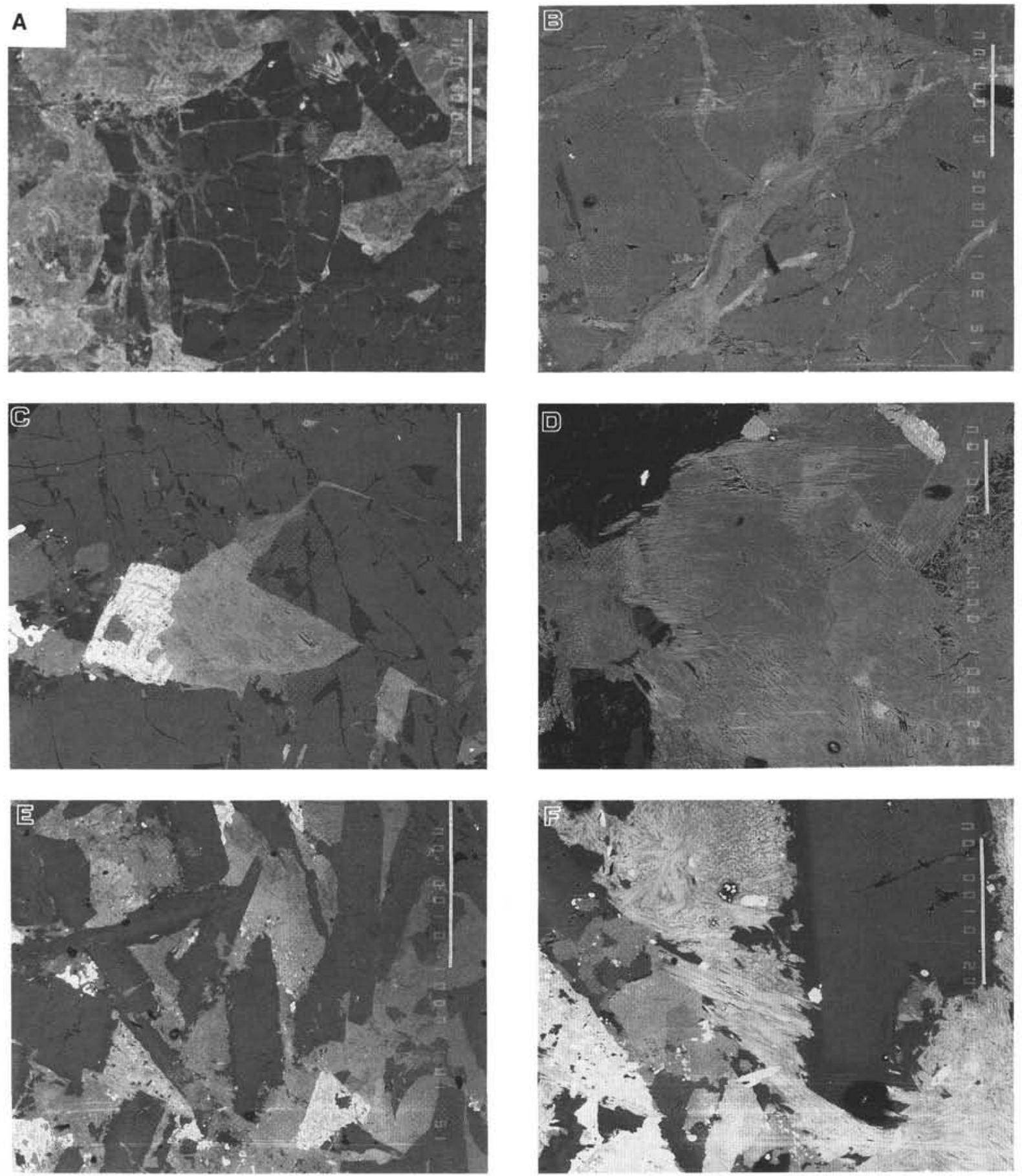

Figure 4. BSE images of diabases from Leg 140 showing the relationships between alteration, intragranular cracks, and grain boundaries. A. Sample 140-504B-209R-2, 20-24 cm. Plagioclase crystals in groundmass showing variations in cracks exploited at different stages of alteration. The crystals are surrounded by actinolite and chlorite from pervasively altered augite. Dark phases within the plagioclase cracks are albite. These cracks have been partially overprinted by chlorite and actinolite fill. The later alteration phases modify the crystal margins isolating crystal fragments but have only reactivated about $50 \%$ of cracks in the inner portions of the crystal. Scale bar $=500 \mu \mathrm{m}$. B. Sample 140-504B-209R-2, 20-24 cm. Detail of thermal crack exploitation by alteration phases in plagioclase crystal. Dark patches of albite can be seen growing out into the surrounding crystal from hairline cracks. Randomly oriented fibrous chlorite and actinolite are the dominant fracture fill. Scale bar $=100 \mu \mathrm{m}$. C. Sample 140-504B-186R-1, 71-76 cm. Dense arrays of albite-filled cracks in plagioclase. The cracks typically display irregular margins associated with small "pull-apart" structures and invasion of albite into the surrounding crystal. The brightest phase is magnetite, and the lighter fibrous phase is actinolite replacing augite. Scale bar $=500 \mu \mathrm{m}$. D. Sample 140-504B-191R-1, 41-43 cm. Relict grain boundaries of augite are still preserved in the matrix even though the grains are completely replaced by actinolite. Within the grains, actinolite shows a strong preferred orientation but changes significantly between grains. Minor kinking of actinolite fibers is evident. Scale bar $=100 \mu \mathrm{m}$. E., F. Sample 140-504B-213R-1, 72-73 cm. Relict groundmass texture after pervasive alteration of augite. In contrast to the prevailing euhedral groundmass and phenocryst plagioclase morphologies, the plagioclase crystals in this sample have ragged edges where chlorite and actinolite are invading the grain boundaries. Figure $5 \mathrm{~F}$ presents a close-up of the region indicated in Figure 5E showing the randomly oriented fibrous alteration phases. Scale bar for $(\mathrm{E})=500 \mu \mathrm{m}$; scale bar for $(\mathrm{F})$ $=100 \mu \mathrm{m}$. 
to make multiple traverses. Each traverse was a minimum of $10 \mathrm{~mm}$ in length, spaced at $1.00 \mathrm{~mm}$. A minimum of 50 grains of each phase and at least 300 cracks in each phase were measured. Fracture densities were calculated separately for each plagioclase and augite crystal in each sample. Olivine crystals are generally too altered, causing development of shrinkage cracks during the preparation process, to provide reliable fracture data. The mean grain size for each phase was also calculated using the linear intercept method, averaging the distance between grain boundaries for each phase for each section examined. For this study we are concerned only with the relative variations in grain size between the different samples investigated. We have not applied stereological corrections to account for the contrasting grain shapes between plagioclase and augite and reduced grain-size estimates as a consequence of sectioning. Crack density counts included fractures which were filled with any alteration phase(s), including staining along healed crack arrays, commonly exploited by hairline thermal cracks. Transgranular hairline cracks without alteration phases were not included as many of these were probably induced by drilling. As transgranular cracks are comparatively rare on thinsection scale only intragranular crack densities were calculated.

Table 1 shows calculated fracture densities and mean grain sizes for plagioclase and pyroxenes in nine samples. The pyroxene crystals have an overall larger grain size than the plagioclase crystals, but the grain size does not appear to cause significant variations in fracture densities for each phase in each sample. All of the sections counted show that the intragranular fracture density for augite is higher than that for plagioclase. The highest and lowest fracture density values are 21.1 and $9.7 \mathrm{cracks} / \mathrm{mm}$ for augite and 11.13 and $4.64 \mathrm{cracks} / \mathrm{mm}$ for plagioclase. Comparisons of the fracture density ratio for plagioclase and augite with the grain-size difference for the two phases in each sample suggest a weak correlation between them (Table 2). An increasing grain-size difference (smaller plagioclase relative to augite) appears to reduce the fracture density ratio with more fracturing in augite relative to plagioclase. This may reflect textural differences associated with larger grain-size contrasts and associated differences in the contiguity of phases. As the grain sizes have not been stereologically corrected and the data set is limited, this relationship is only tentatively proposed and will form the focus of future work. Our preliminary results, however, suggest that it may be possible to contour a fracture density to grain size difference relationship for modal compositions in texturally similar samples if we expanded the data set to a broader range of grain sizes.

\section{INFLUENCE OF COOLING AND ALTERATION ON STRAIN LOCALIZATION: DISCUSSION}

Investigations of strain localization to date have focused primarily on the effects of crystallographic preferred orientation, recrystallization, phase changes, fluid weakening and thermal softening, and frictional and dilational hardening. The crystallization and alteration histories of the Hole 504B diabases provide new insights to the earliest controls on strain localization in the upper ocean crust. The examples discussed above illustrate the time-dependent influence of primary textures and composition on fracture geometries and distribution and subsequent failure mechanisms and sites of alteration. The modal composition of the diabases clearly affects their mechanical response as a consequence of contrasting grain shapes and alteration histories of plagioclase, augite, and olivine. Early heterogeneities are introduced as a consequence of contrasting intragranular cracking between plagioclase and augite during cooling and crystallization. By analogy with other studies of microcracks in fine-grained igneous rocks, the majority of intragranular crack arrays were probably induced as a consequence of volume changes during cooling. Cooling from $800^{\circ} \mathrm{C}$ to $200^{\circ} \mathrm{C}$ reduces the pyroxene volume by about $1.3 \%$, whereas plagioclase decreases by about 1\% (Skinner, 1966; Cooper and Simmons, 1977). Local, minor deviatoric stresses are suggested by numerous deviations from the regular, crystallographically controlled shrinkage crack patterns. These deviations have probably arisen as a consequence of thermal mismatches (Nur and Simmons, 1970) induced by the contrasting volume changes and anisotropy among the three principal diabase phases.

Early post-crystallization strain localization is evident in many plagioclase crystals. Cracks coalesce at grain boundaries between augite and plagioclase and link adjoining plagioclase grains. The intracrystalline shear zone in plagioclase phenocrysts are similar to those reported by Wong and Biegel (1985) in the microstructures generated during experimental deformation of the San Marcos Gabbro but only minimal strain was required to initiate them. Grain shape clearly plays an important role in strain localization, with increased fracture intensity in augites resulting from the angular inclusions and point contacts with plagioclase laths. The dense arrays of intragranular cracks in augite provide closely spaced planes of weakness, which under an applied deviatoric stress, could link to form through going fractures. This does not appear to happen, however, possibly because many of the fractures remain partially healed.

The distribution of alteration phases is clearly influenced by the early stages of cooling crack evolution, which in turn are strongly influenced by the primary textural features such as grain shape and grain boundary contacts. Volume changes accompanying the alteration may also induce deviatoric stresses (Ramsay and Wood, 1973; Beach, 1980). The contrasting densities of fracture arrays in plagioclase and pyroxene phases have influenced the contrasting styles and sites of alteration. In plagioclase the alteration is predominantly fracture controlled, whereas the pyroxene crystals are replaced by patches of fibrous amphibole with less evidence for discrete fracture control. Early alteration is localized as grain boundaries in augite, whereas plagioclase grain boundaries are rarely altered unless they are close to or within pervasive alteration zones such as veins. The progressive alteration history also modifies crack geometries and porosity.

Discrete planar cracks filled with albite have developed into cracks with irregular width where albite has grown out from these zones into the surrounding crystal. Only a limited percentage of cracks in the plagioclase are reactivated by subsequent platy and fibrous alteration phases which tend to be restricted to crack traces. In augite, the extensive actinolite replacement has obliterated evidence for early fracture control on alteration but generates local fabric anisotropies. The consistent orientation of actinolite fibers within relict crystals is clearly controlled by the primary crystallographic orientations and varies from grain to grain. Interpretations of the syn-tectonic textures in cataclastic zones need to take these primary preferred orientations into account. The early distribution of thermal cracks also exerts a strong influence on the shape and size of fragments isolated within more highly altered zones and veins. Where augite is pervasively altered the diabase consists of a network of plagioclase laths surrounding actinolite and chlorite. The strength of the diabase in this instance will be strongly dependent upon the modal abundance of plagioclase and the primary textural relations. If the plagioclase grains are closely connected, then they will form a supporting framework, but where augite is more abundant and the plagioclase laths are isolated, the strength of the diabase will be controlled by the deformation of actinolite and chlorite.

The potential weakening effects due to the precipitation of fibrous or platy alteration phases in microcracks was alluded to by Kranz (1983) but has yet to be incorporated in detailed rheological models for failure in the ocean crust. Thermal cracks, generated on cooling, provide early access to circulating fluids facilitating the precipitation of alteration phases. The ubiquitous presence of fluids in the ocean crust means that the strength of cooling flaws could be significantly reduced as a consequence of subcritical fracture propagation, hydrolytic weakening, or geometrical softening. Hydrothermal reaction progress modifies grain shapes, reducing the impact of angular grain contacts which act as stress risers and generating locally high fracture densities.

Examining the undeformed reference section provided by Hole $504 \mathrm{~B}$ provides some interesting insights into the variable macroscopic 

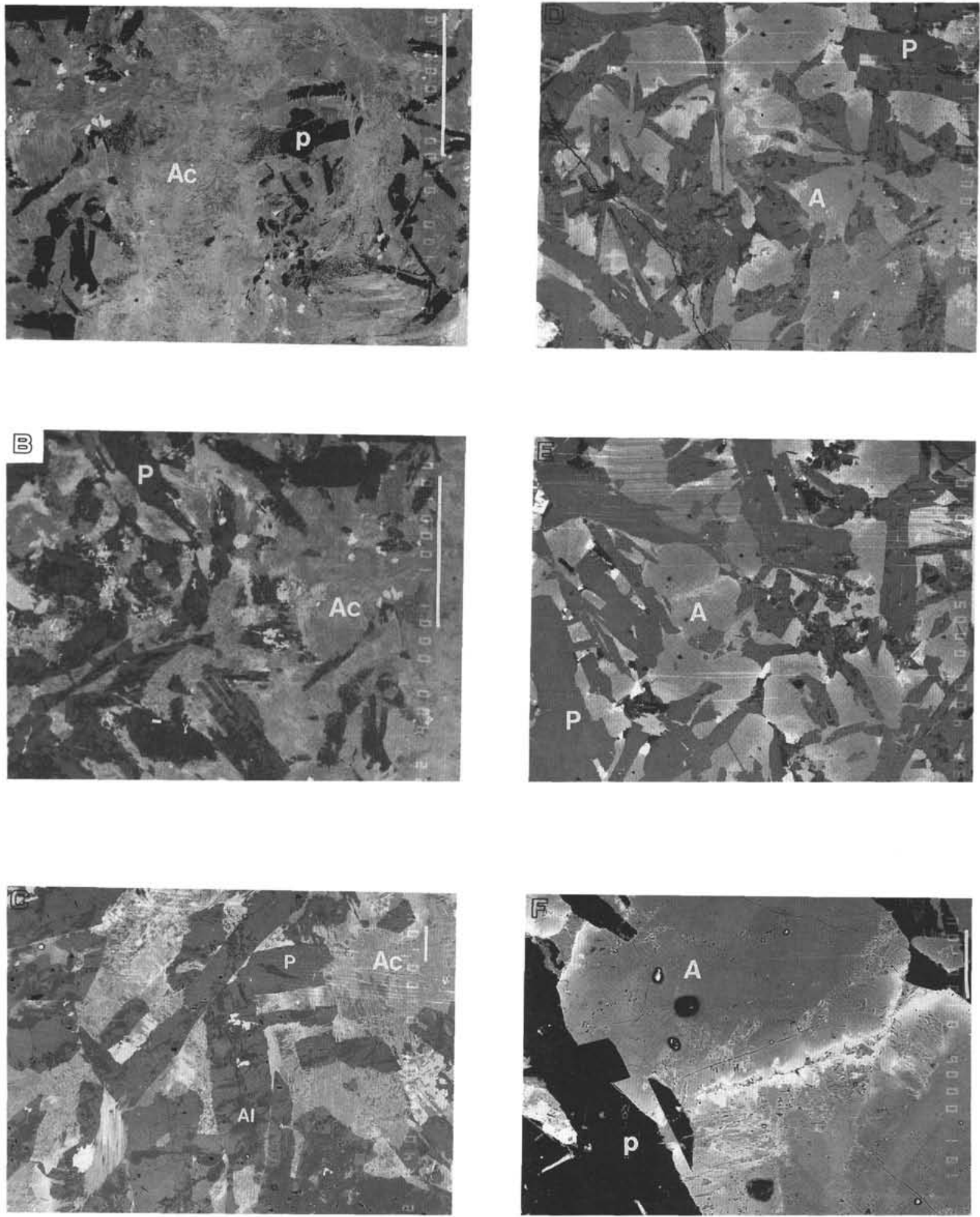

Figure 5. Sequence of BSE images showing the progressive textural changes from the core of an alteration vein into the surrounding wall rock (5A-5E). Sample 140-504B-189R-1, 106-110 cm. See text for discussion. A high-contrast BSE image $(5 F)$ reveals the subgrain structure that overprints a weak compositional zoning in the augite. $(\mathrm{A})$ in $(5 \mathrm{E})$ shows the location of $(5 \mathrm{~F}) . \mathrm{P}=$ plagioclase; $\mathrm{A}=$ augite; $\mathrm{Ac}=$ actinolite/actinolite + chlorite; $\mathrm{Al}=$ albite; $\mathrm{Scale}$ bar for $(\mathrm{A}, \mathrm{B}, \mathrm{E})=$ $1000 \mu ;(\mathrm{C}, \mathrm{F})=100 \mu \mathrm{m} ;(\mathrm{D})=500 \mu \mathrm{m}$. 
Table 1. Mean grain size, modal composition, and intragranular fracture densities for nine diabase samples from Leg 140.

\begin{tabular}{|c|c|c|c|c|c|c|c|}
\hline \multirow[t]{2}{*}{$\begin{array}{l}\text { Core, section. } \\
\text { interval }(\mathrm{cm})\end{array}$} & \multicolumn{2}{|c|}{$\begin{array}{l}\text { Mean } \\
\text { grain size } \\
(\mathrm{mm})\end{array}$} & \multicolumn{2}{|c|}{$\begin{array}{c}\text { Modal \% } \\
\text { (phenocryst/ } \\
\text { groundmass) }\end{array}$} & \multicolumn{2}{|c|}{$\begin{array}{c}\text { Mean } \\
\text { fracture } \\
\text { density } \\
\text { (cracks } / \mathrm{mm})\end{array}$} & \multirow[t]{2}{*}{$\begin{array}{c}\text { Fracture } \\
\text { density } \\
\text { ratio } \\
\text { (P/A) }\end{array}$} \\
\hline & P & A & $\mathrm{P}$ & A & $\mathrm{P}$ & A & \\
\hline 140-504B- & & & & & & & \\
\hline $194 \mathrm{R}-1,115-118$ & 0.32 & 0.37 & $3 / 65$ & $0.3 / 25$ & 11.13 & 17.00 & 0.65 \\
\hline $200 \mathrm{R}-3,10-12$ & 0.18 & 0.4 & $3 / 50$ & $0.5 / 40$ & 4.64 & 11.27 & 0.41 \\
\hline $209 \mathrm{R}-2,20-24$ & 0.34 & 0.50 & $2 / 55$ & $0.5 / 35$ & 7.34 & 12.23 & 0.60 \\
\hline $210 \mathrm{R}-1,30-33$ & 0.19 & 0.45 & $0.5 / 55$ & $0.15 / 40$ & 4.79 & 13.41 & 0.35 \\
\hline $211 \mathrm{R}-1,129-131$ & 0.21 & 0.53 & $0.5 / 55$ & $0.15 / 40$ & 6.41 & 3.42 & 0.48 \\
\hline $213 \mathrm{R}-1.72-73$ & 0.32 & 0.53 & $0.5 / 60$ & $0.15 / 35$ & 6.86 & 9.7 & 0.71 \\
\hline $216 \mathrm{R}-1.66-68$ & 0.14 & 0.28 & $0.8 / 50$ & $0.2 / 45$ & 11.07 & 21.1 & 0.52 \\
\hline $226 \mathrm{R}-2,74-76$ & 0.33 & 0.73 & $0.5 / 55$ & -135 & 6.24 & 12.18 & 0.51 \\
\hline $227 \mathrm{R}-1,110-114$ & 0.31 & 0.53 & $0.5 / 55$ & -135 & 8.00 & 16.98 & 0.47 \\
\hline
\end{tabular}

Note: $\mathrm{P}=$ plagioclase $; \mathrm{A}=$ augite.

response of experimentally deformed samples. For example, experimental work (Kronenberg and Shelton, 1980) has shown that there are two modes of brittle deformation in the Maryland diabase within the brittle-ductile transition: a low-temperature mode $\left(<\sim 800^{\circ} \mathrm{C}\right)$, in which the plagioclase is stronger, and a high-temperature mode $\left(>\sim 800^{\circ} \mathrm{C}\right)$, in which the clinopyroxene is stronger. We suggest that in natural samples from the ocean crust, the primary textures and alteration of diabases will also cause varying mechanical response within the brittle regime at temperatures below $600^{\circ} \mathrm{C}$. Early strain localization features in weakly altered diabases suggest that transgranular cracks nucleate within plagioclase crystals. In more altered diabases from Hole 504B, the more extensive augite alteration may cause pyroxene to behave as the weaker phase. A change in the mechanical response, however, may not be evident if the diabase is still supported by a framework of plagioclase crystals.

\section{SUMMARY}

Microstructural investigations of Hole 504B diabases demonstrate the role of textural and alteration histories in influencing strain localization. Even though the samples are relatively undeformed, they provide a valuable record of the sites of early weaknesses and the factors that influence their timing and location. Our observations suggest that the time-dependent mechanical response will be strongly dependent on the modal composition and primary textural relations that influence the nature of intercrystalline contacts. The modal composition influences the extent of modal mismatches whereas the grain shapes influence the location of stress concentration where fracture intensity increases. Fracture networks early in the diabase cooling history are strongly influenced by crystallographic planes which subsequently influence alteration patterns. Post-crystallization fractures reactivate healed cracks that trapped bubbles of melt. We suggest that the contrasting sites, extent and distribution of alteration phases in plagioclase and augite crystals promoted further mechanical contrasts either during variable hydrothermal conditions on axis or as the diabases moved off-axis. Preliminary fracture density data show a consistent contrast between the intragranular fracture densities of plagioclase and augite crystals. More extensive investigations of stereologically corrected grain sizes and fracture densities of different phases are needed to investigate the interrelationships between modal composition, grain-size contrast and fracture density ratio between plagioclase and augite.

The Hole 504B diabases provide a valuable reference for further investigations of strain localization in the upper ocean crust. Advances in constraining the detailed rheology of the ocean crust at spreading centers would benefit from experimental deformation of texturally diverse diabase and gabbro samples, altered to different extents.
Table 2. Comparison of grain size difference and fracture density ratio for plagioclase and augite grains (in ascending order of grain size difference).

\begin{tabular}{lcc}
\hline $\begin{array}{c}\text { Core, section, } \\
\text { interval }(\mathrm{cm})\end{array}$ & $\begin{array}{c}\text { Grain } \\
\text { size } \\
\text { difference }\end{array}$ & $\begin{array}{c}\text { Fracture } \\
\text { density } \\
\text { ratio }\end{array}$ \\
\hline 140-504B- & & \\
194R-1, 115-118 & 0.05 & 0.65 \\
216R-1.66-68 & 0.14 & 0.52 \\
209R-2, 20-24 & 0.16 & 0.60 \\
213R-1, 72-73 & 0.21 & 0.71 \\
227R-1.110-114 & 0.22 & 0.47 \\
200R-3, 10-12 & 0.26 & 0.41 \\
210R-1, 30-33 & 0.26 & 0.35 \\
211R-1, 129-131 & 0.32 & 0.48 \\
226R-2.74-76 & 0.40 & 0.51 \\
\hline
\end{tabular}

\section{REFERENCES*}

Adamson, A.C., 1985. Basement lithostratigraphy, Deep Sea Drilling Project Hole 504B. In Anderson, R.N., Honnorez, J., Becker, K., et al., Init. Repts. DSDP, 83: Washington (U.S. Govt. Printing Office), 121-127.

Agar, S.M., 1990. Fracture evolution in the upper ocean crust: evidence from DSDP Hole 504B. In Knipe, R.J., and Rutter, E.H. (Eds.), Deformation Mechanisms, Rheology and Tectonics. Geol. Soc. Spec. Publ. London, 54:41-50.

- 1991. Microstructural evolution of a fault zone in the upper ocean crust: an example from DSDP Hole 504B. J. Geodyn., 13:119-140.

Agar, S.M., Prior, D.J., and Behrmann, J.H., 1989. Back-scattered electron imagery of the tectonic fabrics of some fine-grained sediments: implications for fabric nomenclature and deformation processes. Geology, 17:901-904.

Anderson, R.N., and Zoback, M.D., 1983. The implications of fracture and void distribution from bore-hole televiewer imagery for the seismic velocity of the upper oceanic crust at Deep Sea Drilling Project Holes 501 and 504B. In Cann, J.R., Langseth, M.G., Honnorez, J., Von Herzen, R.P., White, S.M., et al., Init. Repts. DSDP, 69: Washington (U.S. Govt. Printing Office), 255-270.

Beach, A., 1980. Retrogressive metamorphic processes in shear zones with special reference to the Lewisian complex. J. Struct. Geol., 2:257-263.

Becker, K., Sakai, H., et al., 1988. Proc. ODP, Init. Repts., 111: College Station, TX (Ocean Drilling Program).

Cannat, M., Bideau, D., and Bougault, H., 1992. Serpentinized peridotites and gabbros in the Mid-Atlantic Ridge axial valley at $15^{\circ} 37^{\prime} \mathrm{N}$ and $16^{\circ} 52^{\prime} \mathrm{N}$. Earth Planet. Sci. Lett., 109:87-106.

Caristan, Y., 1982. The transition from high temperature creep to fracture in Maryland diabase. J. Geophys. Res., 87:6781-6790.

Cooper, H.W., and Simmons, G., 1977. The effect of cracks on the thermal expansion of rocks. Earth Planet. Sci. Lett., 36:404-412.

Fox, P.J., and Stroup, J.B., 1981. The plutonic foundation of the oceanic crust. In Emiliani, C. (Ed.), The Sea (Vol. 7): The Oceanic Lithosphere: New York (Wiley), 119-218.

Fredrich, J.T., and Wong, T.-F., 1986. Mechanics of thermally induced cracking in three crustal rocks. J. Geophys. Res., 91:12743-12764.

Goetze, C., and Brace, W.F., 1972. Lab observations of high temperature rheology of rocks. Tectonophysics, 12:583-600.

Griffith, A.A., 1920. The phenomena of rupture and flow in solids. Philos. Trans. R. Soc. London A, 221:163-198.

Griggs, D.T., Turner, F.J., and Heard, C.H., 1960. Deformation of rocks at $500^{\circ} \mathrm{C}$ to $800^{\circ} \mathrm{C}$. In Griggs, D.T., and Handin, J. (Eds.), Rock Deformation. Mem.-Geol. Soc. Am., 79:39-104.

Hadizadeh, J., and Rutter, E.H., 1983. The low temperature brittle-ductile transition in a quartzite and the occurrence of cataclastic flow in nature. Geol. Rundsch., 72:493-509.

\footnotetext{
Abbreviations for names of organizations and publications in ODP reference lists follow the style given in Chemical Abstracts Service Source Index (published by American Chemical Society).
} 
Helmstaedt, H., and Allen, J.M., 1977. Metagabbronorite from DSDP Hole 334: an example of high temperature deformation and recrystallization near the Mid-Atlantic ridge. Can. J. Earth Sci., 14:886-898.

Hey, R.N., Kleinrock, M.C., Miller, S.P., Atwater, T.M., and Searle, R.C., 1986. SeaBeam/deep-tow investigation of an active oceanic propagating rift system, Galapagos $95.5^{\circ}$ W. J. Geophys. Res., 91:3369-3393.

Hoagland, R.G., Hahn, G.T., and Rosenfield, A.R., 1973. Influence of microstructure on fracture propagation in rock. Rock Mech., 5:77-106.

Hobbs, B.E., Mulhaus, H.-B., and Ord, A., 1990. Instability, softening and localization of deformation. In Knipe, R.J., and Rutter, E.H. (Eds.), Deformation Mechanisms, Rheology and Tectonics. Geol. Soc. Spec. Publ. London, 54:41-50.

Honnorez, J., Alt, J.C., Honnorez, B.M., Laverne, C., Muehlenbachs, K. Saltzman, E., and Ruiz, J., 1985. Stockwork-like sulfide mineralization in young oceanic crust: Deep Sea Drilling Project Hole 504B. In Anderson, R.N., Honnorez, J., Becker, K., et al., Init. Repts. DSDP, 83: Washington (U.S. Govt. Printing Office), 263-282.

Johnson, H.P., and Embley, R.W., 1990. Axial seamount: an active ridge axis volcano on the central Juan de Fuca ridge. J. Geophys. Res., 95:1268912696.

Kappel, E.S., and Normark, W.R., 1987. Morphometric variability with the axial zone of the southern Juan de Fuca Ridge: interpretations from SeaMARC II, SeaMARC I and deep-sea photography. J. Geophys. Res., 92:11291-11302.

Kinoshita, H., Furuta, T., and Pariso, J., 1989. Downhole magnetic field measurements and paleomagnetism, Hole 504B, Costa Rica Ridge. In Becker, K., Sakai, H., et al., Proc. ODP, Sci. Results, 111: College Station, TX (Ocean Drilling Program), 147-156.

Kowallis, B.J., Roeloffs, E.A., and Wang, H.F., 1982. Microcrack studies of basalts from the Iceland Research Drilling Project. J. Geophys. Res. 87:6650-6656.

Kranz, R.L., 1983. Microcracks in rocks, a review. Tectonophysics, 100:449480 .

Kronenberg, A.K., and Shelton, G.L., 1980. Deformation microstructures in experimentally deformed Maryland diabase. J. Struct. Geol., 2:341-353.

Macdonald, K.C., 1982. Mid-ocean ridges: fine scale tectonic, volcanic and hydrothermal processes within the plate boundary zone. Annu. Rev. Earth. Planet. Sci., 10:155-190

Macdonald, K.C., Sheirer, D.S., and Carbotte, S.M., 1991. Mid-ocean ridges: discontinuities, segments and giant cracks. Science, 253:986-994.

Morin, R.H., Newmark, R.L., Barton, C.A., and Anderson, R.N., 1990. State of lithospheric stress and borehole stability at Deep Sea Drilling Project Site 504B, eastern Equatorial Pacific. J. Geophys. Res., 95:9293-9303.

Newmark, R.L., Anderson, R.N., Moos, D., and Zoback, M.D., 1985. Sonic and ultrasonic logging of Hole 504B and its implications for the structure, porosity, and stress regime of the upper $1 \mathrm{~km}$ of the oceanic crust. In
Anderson, R.N., Honnorez, J., Becker, K., et al., Init. Repts. DSDP, 83: Washington (U.S. Govt. Printing Office), 479-510.

Newmark, R.L., Zoback, M.D., and Anderson, R.N., 1984. Orientation of in situ stresses in the oceanic crust. Nature, 311:424-428.

Nur, A., and Simmons, G., 1970. The origin of small cracks in igneous rocks. Int. J. Rock Mech. Min. Sci. Geomech. Abstr., 7:307-312.

Paterson, M.S., 1978. Experimental Rock Deformation: The Brittle Field: New York (Springer-Verlag).

Ramsay, J.G., and Wood, D.S., 1973. The geometric effects of volume change during deformation processes. Tectonophysics, 1:263-277.

Richter, D., and Simmons, G., 1977. Microcracks in crustal igneous rocks: microscopy. In Heacock, J.G., Keller, G.V., Oliver, J.E., and Simmons, G. (Eds.), The Earth's Crust. Am. Geophys. Union Monogr., 2:149-180.

Rovetta, M.R., Blacic, J.D., and Delaney, J.R., 1987. Microfracture and crack healing in experimentally deformed peridotite. J. Geophys. Res., 92:12902-12910.

Rutter, E.H., Peach, C.J., White, S.H., and Johnston, D., 1985. Experimental "syntectonic" hydration of basalt. J. Struct. Geol., 7:251-266.

Shelton, G.L, and Kronenberg, A.K., 1978. Experimentally determined relationship between single and polyphase aggregate strengths. Eos, 59:1185.

Shipboard Scientific Party, 1992. Site 504. In Dick, H.J.B., Erzinger, J., Stokking, L.B., et al., Proc. ODP, Init. Repts., 140: College Station, TX (Ocean Drilling Program), 37-132.

Simmons, G., and Richter, D., 1976. Microcracks in rocks. In Strens, R.G.J. (Ed.), The Physics and Chemistry of Minerals and Rocks: London (Wiley), 105-137.

Skinner, B.J., 1966. Thermal expansion. In Clark, S.P., Jr. (Ed.), Handbook of Physical Constants. Mem.-Geol. Soc. Am., 97:75-96.

Sprunt, E.S., and Brace, W.F., 1974. Direct observation of microcavities in crystalline rocks. Int. J. Rock Mech. Min. Sci., 11:139-150.

Vanko, D.A., and Batiza, R., 1992. Gabbroic rocks from the Mathematician Ridge failed rift. Nature, 300:742-744.

Wang, H.F., Bonner, B.P., Carlson, S.R., Kowallis, B.J., and Heard, H.C., 1989. Thermal stress cracking in granite. J. Geophys. Res., 94:1745-1758.

Wawersik, W.R., and Brace, W.F., 1971. Post failure behaviour of a granite and a diabase. Rock Mech., 3:61-85.

Wong, T.-F., 1982. Geometric probability approach to the characterization and analysis of microcracking in rocks. Mech. Mater., 1:3-17.

Wong, T.-F., and Biegel, R., 1985. Effects of pressure on the micromechanics of faulting in San Marcos gabbro. J. Struct. Geol., 7:737-749.

Date of initial receipt: 26 May 1993

Date of acceptance: 11 May 1994

Ms 137/140SR-025 